\title{
Assessment of Land Use Land Cover Change Detection Using Geospatial Techniques in Southeast Rajasthan
}

\author{
Nuzhat Fatima*, Akram Javed \\ Department of Geology, Aligarh Muslim University, Aligarh, India \\ Email: ^fatimanuzhat05@gmail.com
}

How to cite this paper: Fatima, N., \& Javed, A. (2021). Assessment of Land Use Land Cover Change Detection Using Geospatial Techniques in Southeast Rajasthan. Journal of Geoscience and Environment Protection, 9, 299-319.

https://doi.org/10.4236/gep.2021.912018

Received: October 11, 2021

Accepted: December 28, 2021

Published: December 31, 2021

Copyright $\odot 2021$ by author(s) and Scientific Research Publishing Inc. This work is licensed under the Creative Commons Attribution International License (CC BY 4.0).

http://creativecommons.org/licenses/by/4.0/

\begin{abstract}
Change analysis acquires effective information in the form of maps and statistical data which becomes the central component in spatial planning, monitoring environmental changes, management and utilization of land. The present study makes an attempt to assess the changes in land use land cover using multi-temporal satellite data in south-east Rajasthan. These maps were derived from geocoded dia-positive False Color Composites (FCC's) of IRS 1991, 2001, 2010 \& 2018 using Arc GIS platform. The present study demonstrates the extension, approach and result of change analysis which might be helpful for decision making and sustainable growth. The landscape has been divided into 12 categories. Mining and its associated features were increased whereas forest and open scrub cover shows decreasing trend during the study period. The former increased by $23.82 \mathrm{~km}^{2}$ while the later shrunk by 26.08 $\mathrm{km}^{2}$. Most significant changes are also witnessed in settlement and industrial areas which shows increment by $8.8 \mathrm{~km}^{2}$ and $1.33 \mathrm{~km}^{2}$. Stone quarrying has destroyed arable land, natural vegetation cover, topsoil, subsoil and consequently the soil profile of the area. On the other hand cultivated land is increasing due to the conversion of uncultivated land and scrub cover with facilitation of irrigation and modern agricultural activities under different government schemes. The study shows that the area of $184.88 \mathrm{~km}^{2}$ has undergone significant spatial and temporal changes during the study period.
\end{abstract}

\section{Keywords}

IRS Data, GIS, Land Use Land Cover, Mining, South-East Rajasthan, India

\section{Introduction}

Land use/land cover (LU/LC) is one of the most important aspects in managing 
the earth's resources and hence acquired much attention from the planners and decision makers. Utilization of land capital by humans according to their purposes give rise to "land use" which is influenced by human requirement, environmental processes and features. Land cover refers to the physical and biological cover over the surface of land, including water, vegetation, bare soil and/or artificial structures (Ellis, 2007). Land use is the intended employment of land management strategy placed on the land cover by human agents or land managers to exploit the land cover and reflects human activities such as industrial zones, residential zones, agricultural fields, grazing, logging and mining among others (Zubair, 2006). Since the 1970s, satellite remote sensing data has been used periodically for dynamic monitoring and quantitative analysis of spatial distribution, aerial extent, location, rate and pattern. India being a developing country has undergone a radical change in LU/LC since the onset of economic revolution in the early 1990s leading to urbanization, industrialization and other human activities at a rapid rate. Recently, issues related to LU/LC change has gained interest among a wide variety of researchers, ranging from those who favor modeling spatio-temporal patterns of land conversion to those who try to understand the causes, impacts and consequences (Verburg et al., 1999; Brown et al., 2000; Theobald, 2001). With the increase in sensor capability in terms of spatial resolution, spectral variability and temporal frequency, even minute changes on the earth's surface can be observed and mapped fairly accurately. Analysis of LU/LC changes is perhaps the most prominent form of global environmental and ecosystem change since they occur at spatial and temporal scales immediately relevant to our daily existence (Lambin, 1997). These transformations have a potential effect on environmental conditions as climate change, loss of biodiversity and atmospheric pollution at all scales (Nagendra et al., 2004; Uy \& Nakagoshi, 2007; Sun et al., 2016).

The present study makes an attempt to utilize multi-temporal IRS data using Visual interpretation method to monitor and assess LU/LC changes in parts of Jhalawar and Kota districts of South Eastern Rajasthan. The study area is known for large-scale quarrying for building stone popularly known as Kota stone. This industry has provided employment to thousands of skilled and unskilled workers of the region and also contributed significantly to the economy of the two districts. Mining and quarrying at a large scale significantly impact land, water and atmosphere that cause land degradation and landscape change (Mondal et al., 2014).

In recent years the stone quarrying and environmental protection conflict have been increased which requires temporal information of local and regional scale (Latifovica, 2005). Surface mining has an adverse effect on flora, fauna and LU/LC practices which are existed in an operational area (Vorovencii, 2011; Suraj, 2014). Various researchers have suggested that the waste produced from different industries like limestone waste, dust and waste slurry produced from polishing and cutting industries should be replaced by cement and concrete indus- 
try to minimize the environmental and ecological issues (Rana et al., 2016; Hemalatha \& Ramaswamy, 2017). The potential use of these industrial wastes conserves the natural resources, reduces the amount of $\mathrm{CO}^{2}$ emission, solves management waste from limestone aggregates, fine dust from crushing and washing processes. Dust emission from limestone extraction is the major practice in the atmosphere (Nartey et al., 2012). The mining operations are especially concentrated on a vegetative cover like agriculture, open scrub areas which excavate the removal of natural vegetation, top-soil, sub-soil in order to reach the aggregate underneath. This alters the physico-chemical properties of the soil and disturbs the landscape features (Al-Joulani, 2008; Shrestha \& Lal, 2011; Chenot et al., 2018). Several studies have been conducted on environmental impacts and processing on limestone, sandstone, marble and granite quarrying (Yavuz Çelik \& Sabah, 2008; Souza et al., 2010; Khyaliya et al., 2017; Li et al., 2019). Also, quarrying causes various health issues like silicosis, tuberculosis, asthma and chest pain due to long term exposure to stone dust (Al-Joulani, 2008; Ahmad, 2014; Agwa-Ejon \& Pradhan, 2018; Singhal \& Goel, 2020). The continuous quarrying had negative results on vegetation and arable land and is prominent that the mining operations fall within the agriculture land. Some authors working on quarrying activities confirmed that stone quarrying has a destructive effect on environment and vegetation (Knowles \& Wareings, 1999; Singh et al., 2000; Darwish et al., 2011; Oke \& Ibansesbhur, 2010). Remote sensing and GIS techniques offer an excellent method for decision makers as an informative and visual analytical tool to monitor the surface mining activities and their impacts on LU/LC. Hence mining areas are detected with the help of visualization of remote sensed data and its procession into thematic maps for monitoring purposes (Schmidt \& Glaesser, 1998; Wright \& Stow, 1999; Akanwa, 2016). Aerial photographs and multispectral satellite data have been used for monitoring LU/LC changes over mining areas with time (Jhanwar, 1996). The study utilizes satellite data pertaining to 1991, 2001, 2010 and 2018 to accesse the LU/LC changes due to quarrying and other activities.

\section{Study Area}

The study area lies in parts of Jhalawar and Kota districts of SE Rajasthan extends between latitudes $24^{\circ} 30^{\prime} \mathrm{N}$ to $24^{\circ} 43^{\prime} 30^{\prime \prime} \mathrm{N}$ and longitudes $75^{\circ} 57^{\prime} 30^{\prime \prime} \mathrm{E}$ to $76^{\circ} 4^{\prime} 30^{\prime \prime} \mathrm{E}$ at the edge of Malwa plateau covering a geographical area of about $288.2 \mathrm{~km}^{2}$. Administratively Jhalawar district is a part of Kota division, adjoining the neighboring state of Madhya Pradesh. It falls in agro-climatic zone-V, hot and humid climate with an average annual rainfall of $900-1000 \mathrm{~mm}$. with maximum and minimum temperatures recorded $47^{\circ} \mathrm{C}$ and $10^{\circ} \mathrm{C}$, respectively. Elevation ranges from $223 \mathrm{~m}$ to $455 \mathrm{~m}$ above msl in which North and North Eastern parts show higher elevation and south and south eastern parts show lower elevation. The location map of the study area is shown in Figure 1.

Geomorphologicaly the area represents different land forms such as valley fill, 


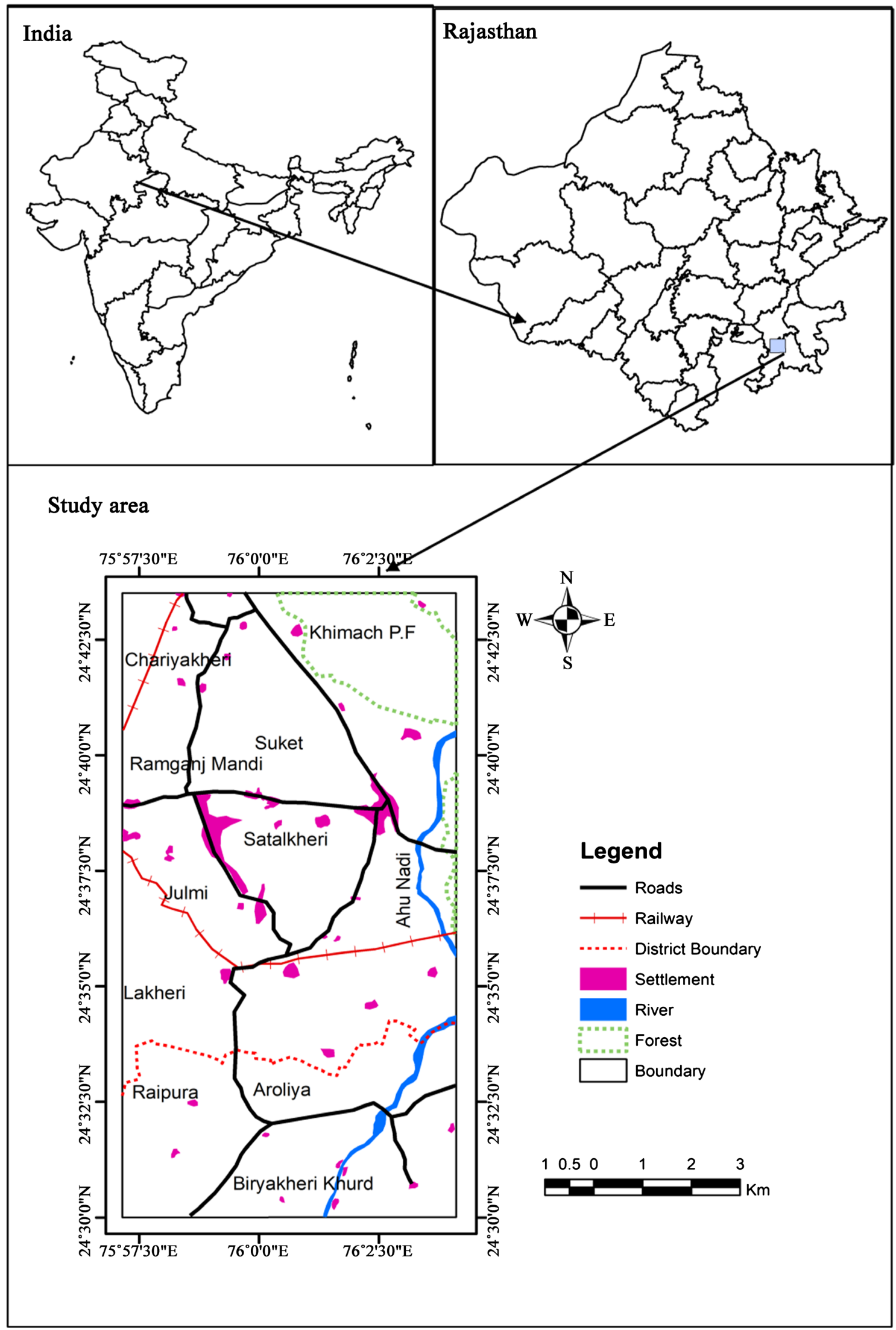

Figure 1. Location map of study area. 
ravines, pediment, buried pediment, structural hill and dissected plateau covered by different LU/LC categories. Kalisindh and Ahu Nadi are two main rivers in the study area which traverse through different land scape and variable terrain providing surface water resources in the region. Fertile plain along with black cotton soil and significant rainfall help in agricultural activities, which are major sources of livelihood in the region. Geologically, the study area is covered by Deccan traps along with rocks of Vindhyan supergroup. The pretrappean rock formations comprise Lower and Upper Vindhyans represented by Jhalarapatan sandstone, Suket shale and limestone, Kaimur sandstone, Rewa shale, sandstone and conglomerates, Ganurgarh shale, Lower Bhander sandstone and limestone, Sirbu shale and limestone. The Vindhyan sandstone and shale are exposed and form linear hills which are stretched northwest to southeast. The major lithological units in the Jhalarapatan and Kota are famous and important sources for stone quarrying and related industrial activity. Large deposits of dimensional limestone in Ramganj Mandi, Cheechat and surrounding area are popularly known as "Kota Stone". Kota stone deposits are geologically part of lower Vindhyan group consisting of Suket shale, Nimbahera limestone and Jhalarapatan sandstone. About $90 \%$ country's production of sandstone, Kota stone and marble has been produced from Rajasthan.

In the past, climate change was largely affected due to natural causes such as volcanic erruptions, Earth's orbit and Ocean currents but today anthropogenic activities accelerate it (Fookes \& Lee, 2007). Anthropogenic activities like population distribution \& industrial growth, mining and other related activities along with evapotranspiration, heat absorption and retention and radiation reflection properties significantly affect not only temperature but precipitation along with total emission of air pollution (Hunt et al., 2017; Aram et al., 2019). The deterioration of stone quarrying due to dust emission changes the concentration of air pollutants over time. As the anthropogenic activities are growing the temperature becomes particularly high through increased concentration of pollutants.

\section{Data Used and Methodology}

Survey of India (SOI) topographical maps No. $45 \mathrm{D} / 2$ and $54 \mathrm{P} / 14$ on 1:50,000 scale were initially used for extracting base line data. Toposheets were mosaicked and area of interest was demarcated to prepare the base map. IRS LISS-III Data (Path-Row: 96-54) of 1991, 2001, 2010 and 2018 were procured from NRSC, Hyderabad, and were subsequently used for LU/LC mapping. Data from same month/season were used in order to minimize the seasonal variations which also exhibit uniform spectral and radiometric attributes or aspects. Multiyear and same season data gives worthwhile information about quantity of conversions from one particular class of LU/LC to another class, their corresponding area, change rate and percentage. Satellite images were georeferenced with respect to coordinate system of toposheets by using map to image transformation. LU/LC 
maps were generated by onscreen digitization in Arc GIS 10.5 which include digitization, creation of polygon topology, assigning of unique id for each polygon and editing. Various LU/LC were identified and delineated on the basis of recognition elements i.e. tone, texture, size, shape, pattern, association and field knowledge. Field verification along with Global Positioning System (GPS) was carried out to verify the spectral signatures and to rectify doubtful areas/features. Pre-field interpretation was finalized after the field inputs and LU/LC maps were then rectified. The change of magnitude and actual location of LU/LC categories were equated by overlay capability of Arc GIS. Change analysis can be done by 'image differencing' which involves subtracting of one data from that of another which results the transitions that have taken place over the temporal period. Area statistics of different categories have been calculated in square kilometers and percentage change so as to quantify the changes in LU/LC over a decade (Table 1). To innumerate the trend of LU/LC change, percentage (\%) change can be computed by dividing observed change by sum of changes multiplied by 100.

Percentage change $=$ Observed change/sum of change $\times 100$.

\section{Result and Discussion}

\subsection{Spectral Signatures of LULC Classes}

Interpretation of IRS data led to the identification and delineation of twelve (12) LU/LC classes namely cultivated land, uncultivated land, forest, plantation, open

Table 1. Land use land cover statistics of the study area (1991-2018).

\begin{tabular}{lcccccccc}
\hline \multirow{2}{*}{$\begin{array}{c}\text { Land Use/Land cover } \\
\text { categories }\end{array}$} & \multicolumn{2}{c}{ LULC (1991) } & \multicolumn{2}{c}{ LULC (2001) } & \multicolumn{2}{c}{ LULC (2010) } & \multicolumn{2}{c}{ LULC (2018) } \\
\cline { 2 - 8 } & $\begin{array}{c}\text { Area } \\
\left(\mathbf{k m}^{2}\right)\end{array}$ & $\begin{array}{c}\text { Area } \\
(\%)\end{array}$ & $\begin{array}{c}\text { Area } \\
\left(\mathbf{k m}^{2}\right)\end{array}$ & $\begin{array}{c}\text { Area } \\
(\%)\end{array}$ & $\begin{array}{c}\text { Area } \\
\left(\mathbf{k m}^{2}\right)\end{array}$ & $\begin{array}{c}\text { Area } \\
(\%)\end{array}$ & $\begin{array}{c}\text { Area } \\
\left(\mathbf{k m}^{2}\right)\end{array}$ & $\begin{array}{c}\text { Area } \\
(\%)\end{array}$ \\
\hline Cultivated Land & 69.5 & 24.15 & 78.1 & 27.1 & 86.8 & 30.1 & 118.45 & 41.9 \\
Uncultivated Land & 120.4 & 41.8 & 108.8 & 37.7 & 113.4 & 39.4 & 79.34 & 27.5 \\
Forest & 7.9 & 2.75 & 7.2 & 2.5 & 6.5 & 2.3 & 5.8 & 2.01 \\
Plantation & 1.7 & 0.58 & 5.5 & 1.9 & 5.8 & 2 & 8.54 & 2.96 \\
Open Scrub & 33.8 & 11.7 & 26.4 & 9.2 & 19.9 & 6.9 & 9.82 & 3.4 \\
Ravines with scrub & 30 & 10.4 & 24.8 & 8.6 & 7.3 & 2.5 & 4.7 & 1.6 \\
Stone quarry & 9.9 & 3.4 & 13.7 & 4.8 & 20 & 6.9 & 28.22 & 9.79 \\
Over burden dump & 7 & 2.4 & 10.2 & 3.5 & 11.6 & 4 & 12.5 & 4.33 \\
Exposed rock/waste land & 3.3 & 1.14 & 6.3 & 2.2 & 6 & 2 & 3.8 & 1.3 \\
Industrial land & 0.3 & 0.1 & 0.4 & 0.1 & 0.5 & 0.2 & 1.63 & 0.56 \\
Settlement/built up & 3.3 & 1.2 & 4.2 & 1.5 & 7.8 & 2.7 & 12.1 & 4.2 \\
Water body/river & 1.1 & 0.38 & 2.6 & 0.9 & 2.6 & 0.9 & 3.3 & 1.1 \\
Total & 288.2 & 100 & 288.2 & 100 & 288.2 & 100 & 288.2 & 100 \\
\hline & & & & & & &
\end{tabular}


scrub, ravines with scrub, stone quarry, overburden dumps, exposed rock/waste land, industrial land, settlement/built up, water body/river. Interpretation of LU/LC categories is based on standard photo recognition elements showing different tones, textures, sizes, patterns, shapes, associations, etc. besides field knowledge. Cultivated land is recognized by bright red tone, smooth texture, contiguous pattern whereas uncultivated land shows grey to dark green tone, coarse texture, regular to irregular pattern often in proximity to cultivated land. They are mainly associated with low lying and plain areas with gentle slope $\left(0^{\circ}\right.$ $11^{\circ}$ ). Elevation ranging low to medium relief zones from 297 - $334 \mathrm{~m}$. Forest shows dark red tone, coarse texture, contiguous to non-contiguous pattern and is associated with moderate to high relief zones (354 - $455 \mathrm{~m})$. Plantation exhibits dark red tone, smooth texture, regular and well defined boundary, mainly intermixed with cultivated and uncultivated land but at places on over burden dumps as well. Open scrub is identified by light pinkish to light green tone, irregular shape and rough texture whereas ravenous land with scrub shows reddish brown tone, coarse texture and its association with adulatory terrain with relatively low (297 - $334 \mathrm{~m}$ ) to moderate (334 - $354 \mathrm{~m}$ ) relief zones. Stone quarry displays whitish cyan tone, rough texture, scattered pattern, depressed topography and signs of human activity. Waste land is identified by its bright tone, smooth texture, scattered pattern and irregular outline. Settlement is recognized by cyan tone, coarse texture, semi-circular pattern and association with roads/ railway lines. Water body appears blue in colour, smooth texture and shows irregular but well defined boundary outline. Land cover dynamics are often connected with land use type of that particular area is generally analogous with vegetation cover and vegetation itself is linked with response of temperature and precipitation. It was found that higher topographical areas are generally associated with forest cover and scrub land, whereas due to human intervention like stone quarrying, fire wood, fodder, etc. other categories have shifted towards these areas like Settlement, Cultivated and Uncultivated land, etc.

\subsection{Change Detection of LULC (1991-2018)}

Thematic maps of year 1991, 2001, 2010 and 2018 were generated as shown in Figures 2 (a)-(d). Comparative analysis of 1991 and 2018 IRS data reveals some substantial changes under different categories in LU/LC due to various natural and anthropogenic activities is shown in Figure 3. It is apparent from statistical data of LU/LC that the dominant categories are cultivated land and uncultivated land which shows that the area is highly under the occupation of agriculture, highly scattered and well distributed throughout the study area. The following LU/LC categories show increases in their geographical area are as follows:

1) Cultivated land has registered growth of $48.95 \mathrm{~km}^{2}$. The cultivated land has expanded from $69.5 \mathrm{~km}^{2}$ in 1991 to $118.45 \mathrm{~km}^{2}$ in 2018 which suggests that, despite the economic growth, many people are still dependent on the traditional agricultural practices. The increase in area may be attributed to conversion of 




(a) 


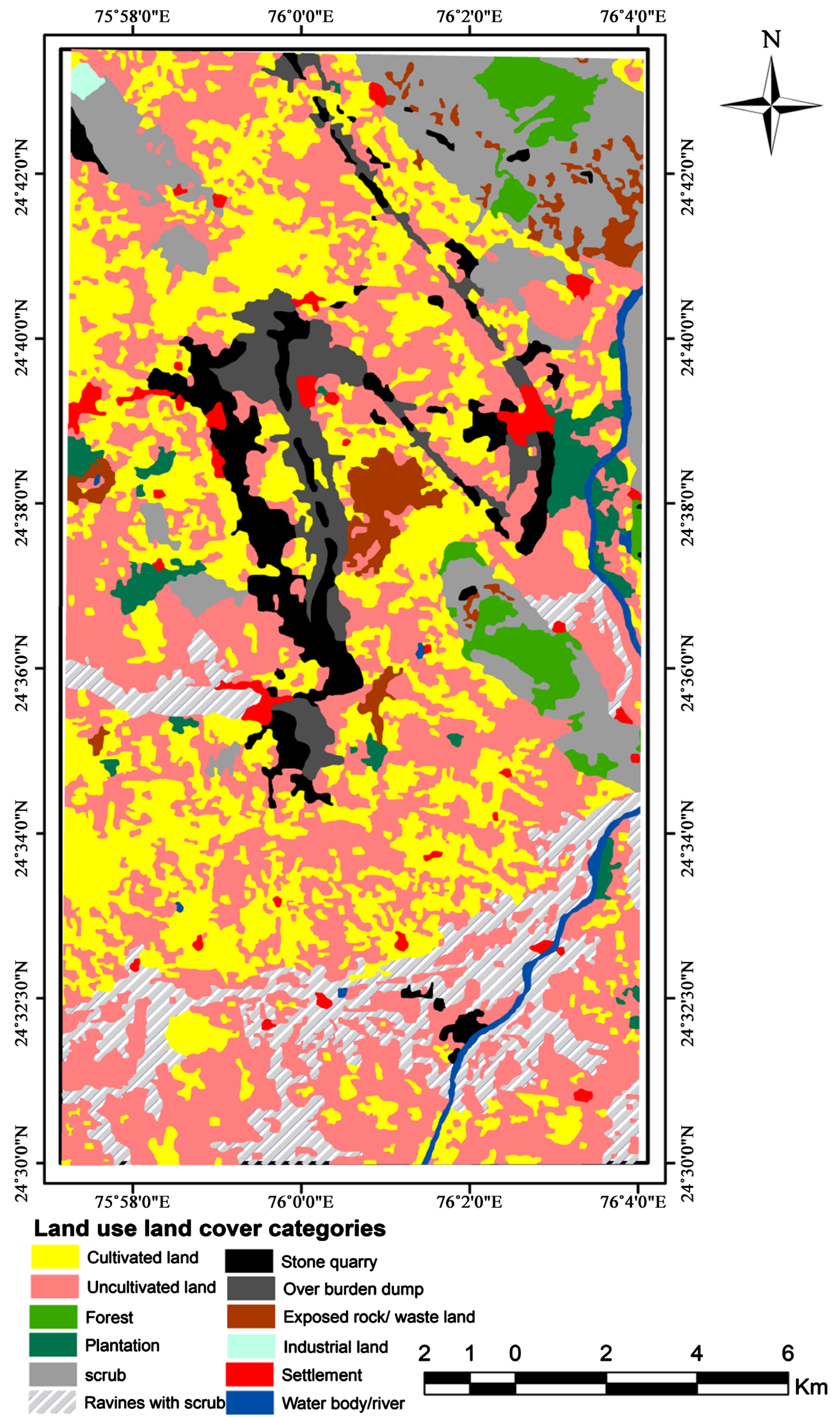

(b) 


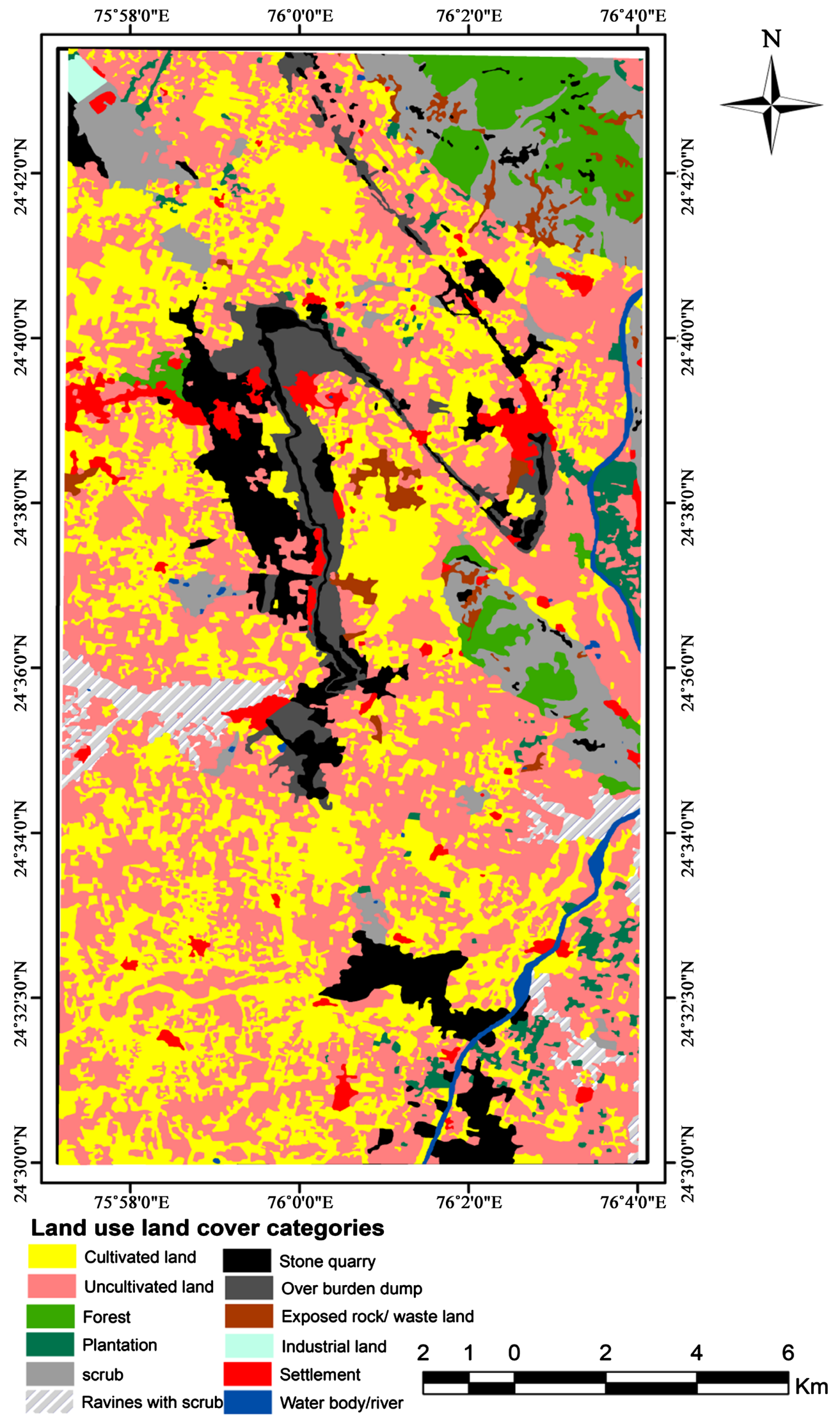

(c) 


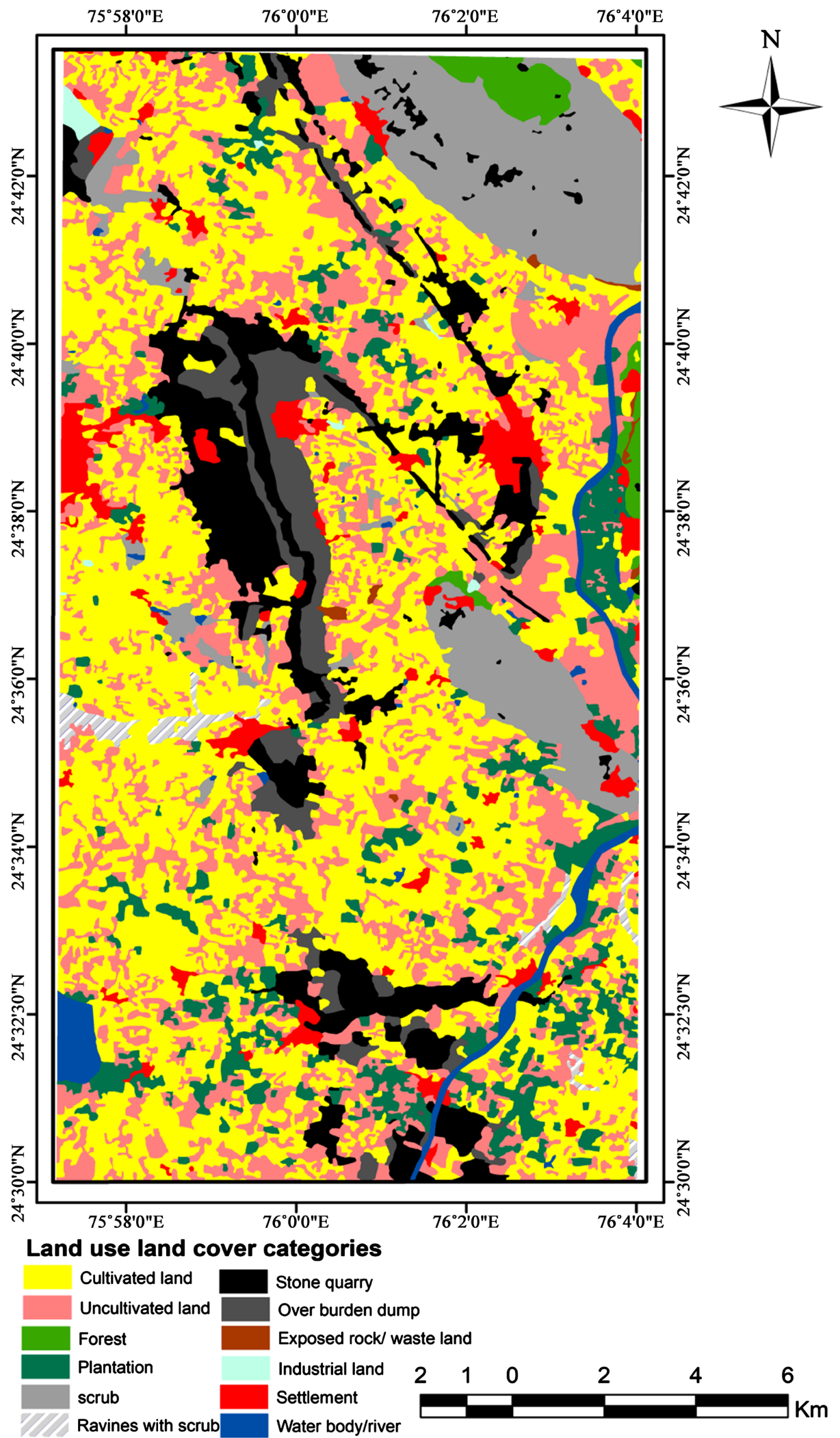

(d)

Figure 2. (a) 1991 LULC map of study area; (b) 2001 LULC map of study area; (c) 2010 LULC map of study area; (d) 2018 LULC map of study area. 


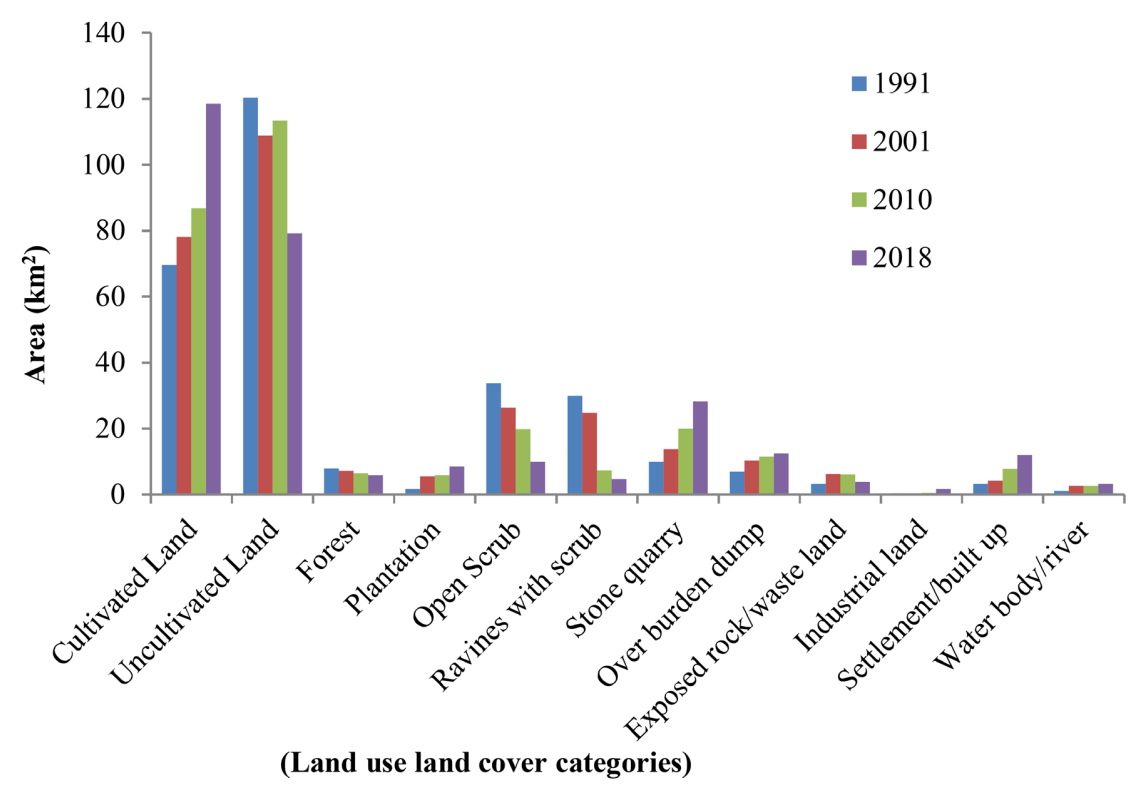

Figure 3. Change in Land use land cover categories during (1991-2018).

uncultivated land, open scrub, ravines with scrub and forest land. With the help of advanced technology, irrigation system and land improved programs, the study area has achieved better productivity in agriculture and horticulture production.

2) Uncultivated area shows decreasing trend from $120.4 \mathrm{~km}^{2}$ in 1991 and $79.34 \mathrm{~km}^{2}$ in 2018 with total decrease of $41.06 \mathrm{~km}^{2}$.

3) It has been clear from LU/LC statistics that the land under plantation shows extension by $6.84 \mathrm{~km}^{2}$ area.

4) Stone quarries, surface rocks and their associated features like overburden dumps have increased by $18.32 \mathrm{~km}^{2}$ (Figure 4(a)). Besides mining, over burden dumps (Figure 4(c)), stone waste (Figure 4(d)), and stone dust generated from polishing and cutting industries (Figure 4(e) \& Figure 4(f))becomes thoughtful issue to decipher how this material should take in use. Overburden dumps have increased $5.5 \mathrm{~km}^{2}$ area. Also the dumping sites for workable limestone are reserved on agricultural arable land (Figure 4(b)). The abandoned mines (Figure 4(g) \& Figure 4(h)) needs land reclamation to resolve the environmental liabilities.

5) The study reveals that there is remarkable population growth because of mining activities and increment of large and small estate industrial growth which has been increased by $8.8 \mathrm{~km}^{2}$ area whereas industrial land has grown by $1.33 \mathrm{~km}^{2}$.

6) Water bodies also increased by $2.2 \mathrm{~km}^{2}$.

On the other hand, categories which show areal reduction in LU/LC from 1991 to 2018 are as follows:

1) Forest cover is decreased by $2.1 \mathrm{~km}^{2}$ by area. Forest were mainly used for fuel wood, grazing, timber, fodder, fruit and tendu.

2) The area is subjected to aridity having sparse vegetation which is responsible to create scrub land. Scrub land is generally prone to deterioration and shows positive effect, reduced by $23.98 \mathrm{~km}^{2}$ whereas ravines with scrub are shrunken by $25.3 \mathrm{~km}^{2}$ area. 

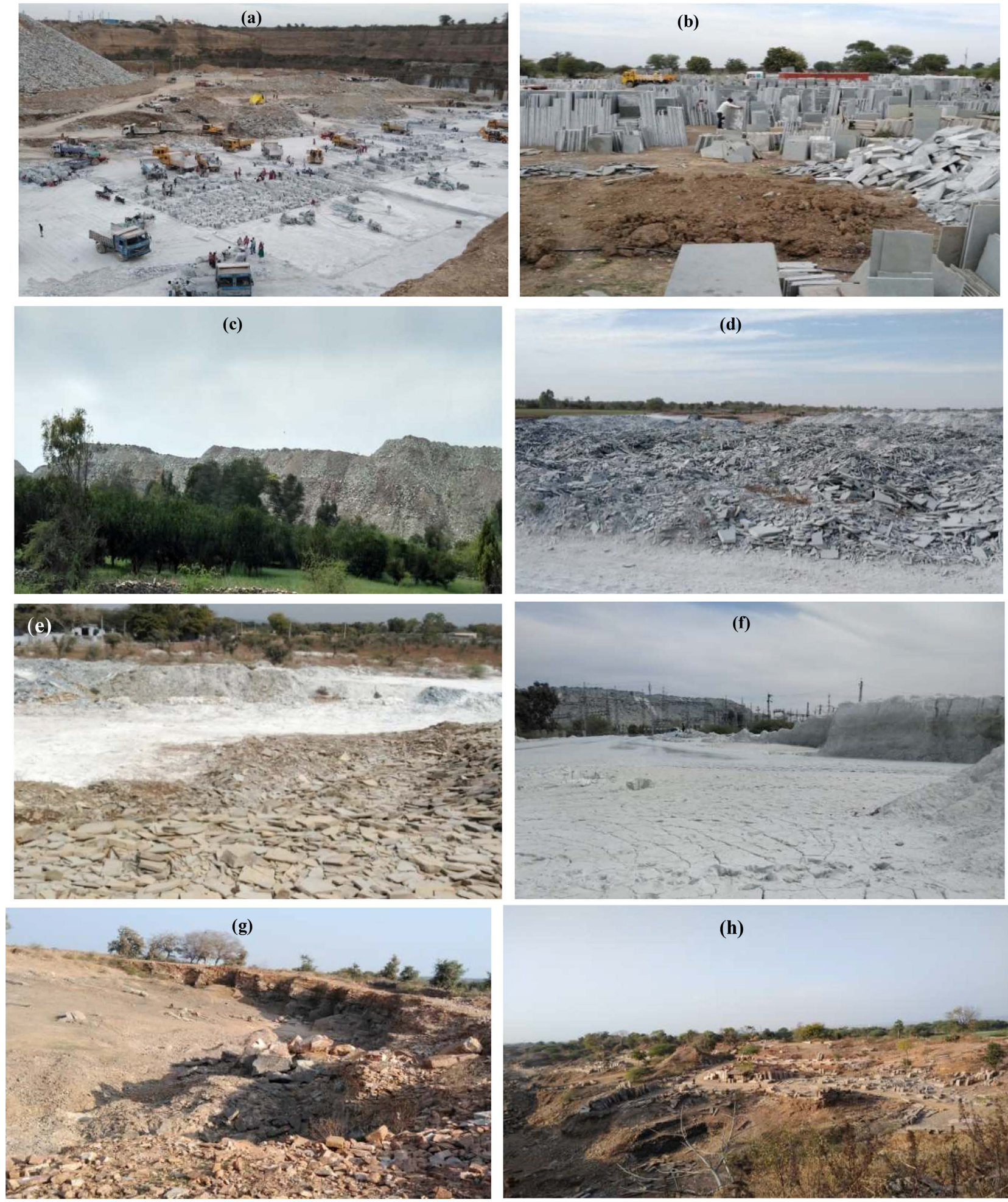

Figure 4. (a) Field photographs of lime stone quarry in progress; (b) Dumping site of workable limestone; (c) Overburden dump; (d) Stone waste; (e) \& (f) Stone dust produced from industries on agricultural land; (g) \& (h) Abandoned mining sites.

3) Rock exposures and waste land has been decreased by $0.5 \mathrm{~km}^{2}$.

The retreating of areas covered with open scrub, ravines with scrub, forest and expanding of cultivated land, plantation, stone quarry, overburden dumps, set- 
tlement/built-up and industrial land in the region was established by the field investigation. The study shows that the area has undergone significant spatial and temporal changes in LU/LC during 1991-2018 as shown in Table 2. The positive changes were observed in cultivated land, plantation, open scrub, ravines with scrub and exposed rock/stone waste. LU/LC analysis shows increase or decrease of area from 1991 to 2018 under different categories as shown in Figure 5. In Jhalawar 5\% and Kota $8 \%$ there is an increase of cultivated land due

Table 2. Land use land cover change statistics of the study area.

\begin{tabular}{|c|c|c|c|c|}
\hline $\begin{array}{l}\text { Land Use/Land cover } \\
\text { categories }\end{array}$ & $\begin{array}{c}\text { Net change } \\
\left(\mathrm{km}^{2}\right) \\
(1991-2001)\end{array}$ & $\begin{array}{c}\text { Net change } \\
\left(\mathrm{km}^{2}\right) \\
(2001-2010)\end{array}$ & $\begin{array}{c}\text { Net change } \\
\left(\mathrm{km}^{2}\right) \\
(2010-2018)\end{array}$ & $\begin{array}{c}\text { Net change } \\
\left(\mathrm{km}^{2}\right) \\
(1991-2018)\end{array}$ \\
\hline Cultivated Land & 8.6 & 8.7 & 31.65 & 48.95 \\
\hline Uncultivated Land & 11.6 & 4.6 & 34.06 & 41.06 \\
\hline Forest & 0.7 & 0.7 & 0.7 & 2.1 \\
\hline Plantation & 3.8 & 0.3 & 2.74 & 6.84 \\
\hline Open Scrub & 7.4 & 6.5 & 10.08 & 23.98 \\
\hline Ravines with scrub & 5.2 & 17.5 & 2.6 & 25.3 \\
\hline Stone quarry & 3.8 & 6.3 & 8.22 & 18.32 \\
\hline Over burden dump & 3.2 & 1.4 & 0.9 & 5.5 \\
\hline Exposed rock/waste land & 3 & 0.3 & 2.2 & 0.5 \\
\hline Industrial land & 0.1 & 0.1 & 1.18 & 1.33 \\
\hline Settlement/built up & 0.9 & 3.6 & 4.43 & 8.8 \\
\hline Water body/river & 1.5 & 0 & 0.7 & 2.2 \\
\hline Total Change & 49.8 & 50 & 99.46 & 184.88 \\
\hline
\end{tabular}

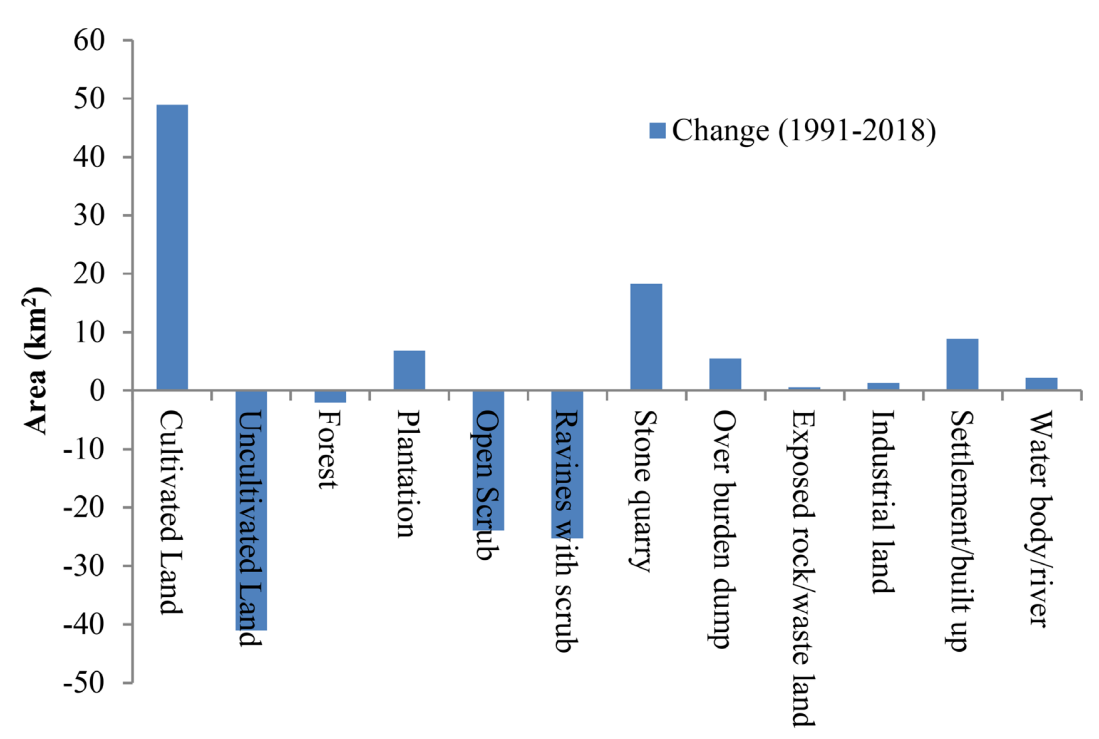

(Land use land cover categories)

Figure 5. Increase and decrease of Land use land cover categories during (1991-2018). 
to irrigation and reclamation of rocky and ravenous areas (Sen \& Gupta, 1978). Agriculture expansion, infrastructure expansion and wood extraction are the major causes of LU/LC changes (Geist \& Lambin, 2002; De Sherbinin, 2002) as crop lands and pastures are the dominant ecosystem on the Earth (Paul \& Lisa, 2011) which are characterized by decline of woodlands, scrub lands, forest and grass lands in time and space (Eshetu \& Hogberg, 2000; Woldeamlak, 2002; Tesfaye et al., 2011; Kindu et al., 2013; Molla, 2014; Alemu et al., 2015). The density of cultivated land is moderate, Kota (43.49\%), Jhalawar (44.41\%) which fall under sub humid zone due to which it receives high rainfall (Sen, 1972).

Positive changes were also observed in mining or stone quarry and over burden dumps. From Figure 6, it is evident that the limestone production shows declining trend between 1999-2000, 2004-2005, 2006-2007, 2009-2010 and after 2010 with increase in stone quarrying the production of limestone is increasing tremendously. The graph shows linear correlation between production and time which indicates that with time the production of limestone is increasing. With increasing demand of limestone and other dimensional stone, large amount of upper part of vegetative cover with soil profile is removed which causes short as well as long term disturbance on landscape and ecosystem. With the help of remote sensing satellite data analysis, the area of $64 \%$ has changed from one LU/LC category to another. Decrease of vegetation cover and increase of stone quarrying not only affects the ecology but have an impact on the climatic conditions also.

The minimum and maximum temperatures were divided in winter, summer and monsoon which significantly increase from 1990 to 2018 (Figure 7(a) \& Figure $7(\mathrm{~b})$ ). The maximum temperature record was $39.25^{\circ} \mathrm{C}$ in 2010 and minimum temperature was $11.41^{\circ} \mathrm{C}$ in 1997 . The maximum and minimum temperature trend depends on atmospheric circulation and local physical geography in different ways like topography, land use land cover changes, urbanization, air pollution, etc. (Turkes \& Sumer, 2004; Dhorde et al., 2009; Tabari \& Talaee, 2011). The average annual rainfall from 1990 to 2018 is $909.02 \mathrm{~mm}$. It is apparent from

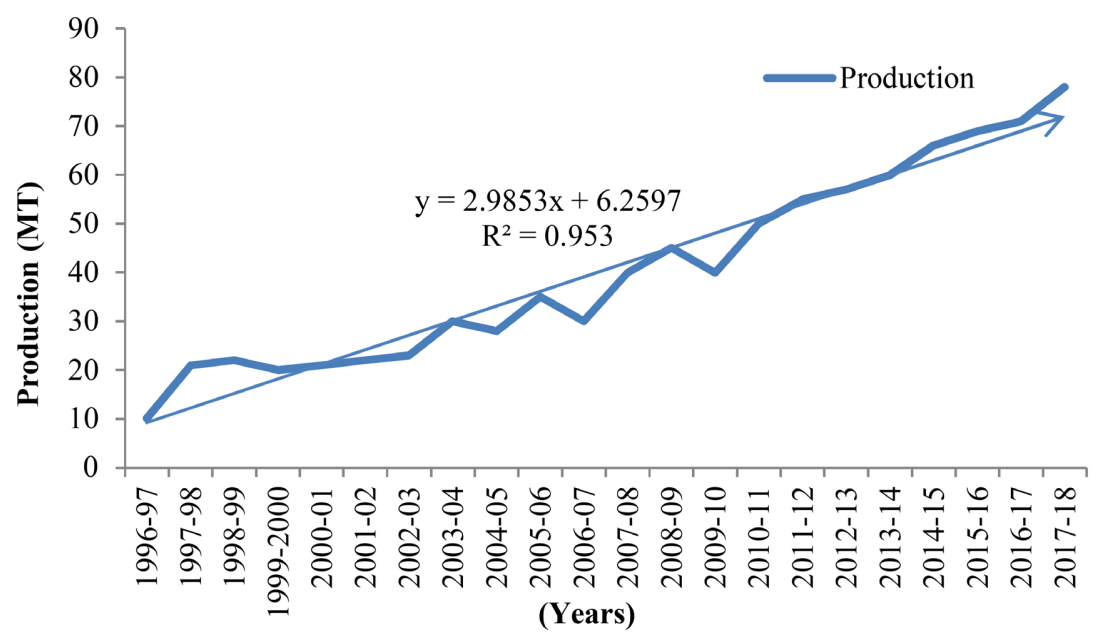

Figure 6. Lime stone production during (1996-2018). 


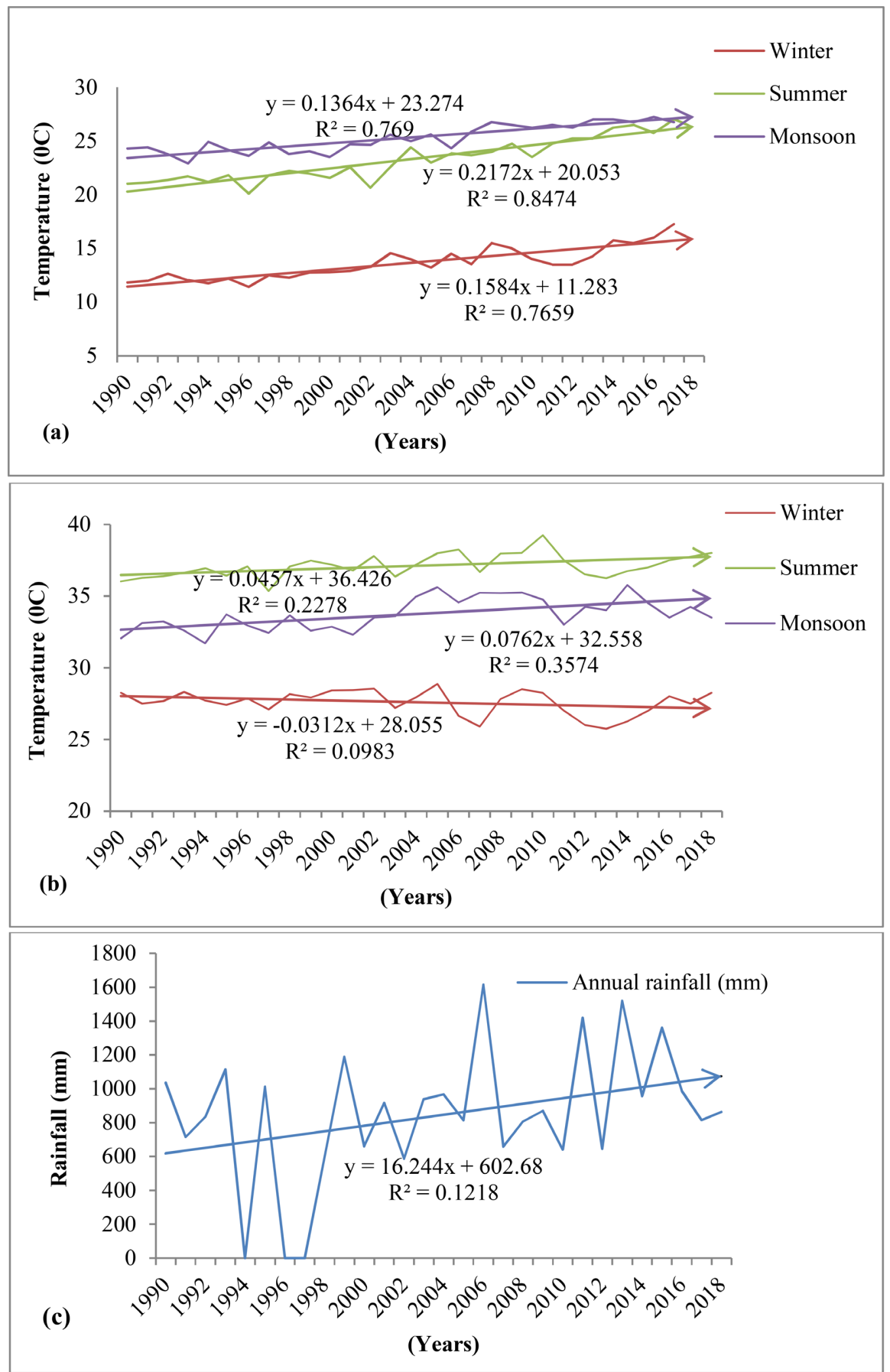

Figure 7. (a) Minimum temperature; (b) Maximum temperature; (c) Annual rainfall during (1991-2018).

Figure $7(\mathrm{c})$ that the average annual rainfall shows zig zag pattern with increasing trend. It gradually inclined from $588 \mathrm{~mm}$ during 2002 to $1614.5 \mathrm{~mm}$ during 2006. There were three drought years namely 1994, 1996 and 1997 which constitute $10.71 \%$ of the total observations. In contrast 2006, 2011, 2013, 2014 were wet years that represent $17.85 \%$ of the total observations. The remaining 20 years receive normal rainfall which represents $71.44 \%$ of the total observations during 
the study period. With increasing rainfall the agriculture production exhibits development and expansion in area.

\section{Conclusion}

Change detection map of the study area possesses rapid change in LU/LC which might be supportive to conserve the threatened areas and devised for providing sustainable development. With the help of multi-temporal satellite data, LU/LC analysis shows dramatic changes especially in stone quarry, forest cover, cultivated land, settlement/built up and industrial area. Updated, accurate information and records are necessary for future planning and environmental consequences of changes. In the vicinity of remote sensing and GIS techniques, the present study demonstrates their applicability to access the changes in LU/LC by using IRS satellite data of the year 1991, 2001, 2010 and 2018. Under the influence of population growth, economy and physical environmental conditions the study area show changes in LU/LC. Physiographically the area is diverse. Open scrub, ravines with scrub in the study area were mainly converted into cultivated, plantation and settlement/built-up classes. Cultivated land and agrobusiness plantation like oranges, mango, guava, mausambi (sweet lemon) etc. show an increase in areal extent which occupies a flat and low lying area with a slope ranging 0 - 9 during the study period. Ramganj-Mandi and Jhalawar are the environmentally most critical areas where extensive limestone mining is carried out. The main impact of mining on environment is land degradation, water pollution, soil loss and public health. The Majority of limestone mining, limestone dumping sites, overburden, and waste rock are carried on agricultural land. As per various government reports every year about 65 - 100 hectares of agricultural land are being removed for mining purposes. But as per demand the land under mining and related activities are increasing every year. Limestone exploitation is carried out by removal of overburden and limestone extraction. The bulk quantity of waste product/overburden dump generated results denuded land-scape change which affects the hydrological profile along with soil and sub-soil. Waste generated from industries produces a large quantity of highly alkaline water at the time of limestone cutting and polishing which reduces the infiltration rate and increases the runoff. Due to mining and industrial setup which becomes the employment sector for stone cutting and polishing has been increased by population explosion. Within 27 years of interval mining and overburden has been increased by $32.82 \mathrm{~km}^{2}$ (3282 Ha) by area. Greater emphasis should given on the dynamic changes between human societies, their environment and ecosystem at a regional scale. Government should take into concern about the land transformations which influence the micro-climate change. The prime factor to overcome the land transformations e.g. deforestation, devastation of mining activities or other changes in natural vegetation is land management. This spatial and temporal framework has led to a greater consideration of LU/LC transition processes. 


\section{Acknowledgements}

We indepthly acknowledge the chairman, Department of Geology, AMU, Aligarh for providing the lab facilities. Thanks to Department of History, AMU, Aligarh provided the SOI Toposheets and NRSC, Hyderabad for IRS data.

\section{Conflicts of Interest}

The authors declare no conflicts of interest regarding the publication of this paper.

\section{References}

Agwa-Ejon, J. F., \& Pradhan, A. (2018). Life Cycle Impact Assessment of Artisanal Sandstone Mining on the Environment and Health of Mine Workers. Environmental Impact Assessment Review, 72, 71-78. https://doi.org/10.1016/j.eiar.2018.05.005

Ahmad, A. (2014). A Study of Miners, Demographics and Health Status in Jodhpur District of Rajasthan, India. International Journal of Development Studies and Research, 3, 113-121. https://www.researchgate.net/publication/266560236_A_study_of_Miners_Demograph ics_and_Health_Status_in_Jodhpur_DIstrict_of_RajasthanIndia

Akanwa, A. O. (2016). The Effect of Quarrying Activities on Vegetation Cover in Ebonyi State, Nigeria. A PhD Thesis from the Centre for Environmental Management and Control (CEMAC), University of Nigeria, Enugu Campus.

Alemu, B., Garedew, E., Eshetu, Z., \& Kassa, H. (2015). Land Use and Land Cover Changes and Associated Driving Forces in North Western Lowlands of Ethiopia. International Research Journal of Agricultural Science and Soil Science, 5, 28-44.

Al-Joulani, N. (2008). Soil Contamination in Hebron District Due to Stone Gutting Industry. Jordan Journal of Applied Sciences-Natural Sciences, 10, 37-50.

Aram, F., García, E.H., Solgi, E., \& Mansournia, S. (2019). Urban Green Space Cooling Effect in Cities. Heliyon, 5, Article ID: e01339. https://doi.org/10.1016/j.heliyon.2019.e01339

Brown, D. G., Pijanowski, C. B., \& Duh, J.-D. (2000). Modeling the Relationships between Land-Use and Land-Cover on Private Lands in the Upper Midwest, USA. Journal of Environmental Management, 59, 247-263. https://doi.org/10.1006/jema.2000.0369

Chenot, J., Jaunatrec, R., Buissonb, E., Bureaud, F., \& Dutoit, T. (2018). Impact of Quarry Exploitation and Disuse on Pedogenesis. CATENA, 160, 354-365. https://doi.org/10.1016/j.catena.2017.09.012

Darwish, T., Khater, C., Jomaa, I., Stehouwer, R., Shaban, A., \& Hamze, M. (2011). Environmental Impact of Quarries on Natural Resources in Lebanon. Land Degradation \& Development, 22, 345-358. https://doi.org/10.1002/ldr.1011

De Sherbinin, A. (2002). Land-Use and Land-Cover Change, A CIESIN Thematic Guide. Center for International Earth Science Information Network of Columbia University. http://sedac.ciesin.columbia.edu/tg/guide_main.jsp.

Dhorde, A., Dhorde, A., \& Gadgil, A.S. (2009). Long-Term Temperature Trends at Four Largest Cities of India during the Twentieth Century. The Journal of Indian Geophysical Union, 13, 85-97.

Ellis, E. (2007). Land Use and Land Cover Change. Encyclopedia of Eart.

Eshetu, Z., \& Hogberg, P. (2000). Reconstruction of Forest Site History in Ethiopian 
Highlands Based on ${ }^{13} \mathrm{C}$ Natural Abundance of Soils. Ambio, 29, 83-89. https://doi.org/10.1579/0044-7447-29.2.83

Fookes, P. G., \& Lee, M. E. (2007). Climate Variation: A Simple Geological Perspective. Geology Today, 23, 66-73. https://doi.org/10.1111/j.1365-2451.2007.00603.x

Geist, H. J., \& Lambin, F. E. (2002). Proximate Causes and Underlying Driving Forces of Tropical Deforestation. BioScience, 52, 143-150. https://doi.org/10.1641/0006-3568(2002)052[0143:PCAUDF]2.0.CO;2

Hemalatha, T., \& Ramaswamy, A. (2017). A Review on Fly Ash Characteristics-Towards Promoting High Volume Utilization in Developing Sustainable Concrete. Journal of Cleaner Production, 147, 546-559. https://doi.org/10.1016/j.jclepro.2017.01.114

Hunt, J. C., Aktas, Y. D., Mahalov, A., Moustaoui, M., Salamanca, F., \& Georgescu, M. (2017). Climate Change and Growing Megacities: Hazards and Vulnerability. Proceedings of the Institution of Civil Engineers: Engineering Sustainability, 171, 314-326. https://doi.org/10.1680/jensu.16.00068

Jhanwar, M. C. (1996). Application of Remote Sensing for Environmental Monitoring in Bijolia Mining Area of Rajasthan. Journal of the Indian Society of Remote Sensing, 24, 255-264. https://doi.org/10.1007/BF03026233

Khyaliya, R. K., Kabeer, A. S. I. K., \& Vyas, K. A. (2017). Evaluation of Strength and Durability of Lean Mortar Mixes Containing Marble Waste. Construction and Building Materials, 147, 598-607. https://doi.org/10.1016/j.conbuildmat.2017.04.199

Kindu, M., Schneider, T., Teketay, D., \& Knoke, T. (2013). Land Use/Land Cover Change Analysis Using Object-Based Classification Approach in Munessa-Shashemene Landscape of the Ethiopian Highlands. Remote Sensing, 5, 2411-2435. https://doi.org/10.3390/rs5052411

Knowles, R., \& Wareing, J. (1999). Economic and Social Geography Made Simple. W. H. Allen (Ed.), Howard and Wyndham Company.

Lambin, E. (1997). Modelling and Monitoring Land Cover Change Processes in Tropical Regions. Progress in Physical Geography: Earth and Environment, 21, 375-393. https://doi.org/10.1177/030913339702100303

Latifovica, R., Fytasb, K., Chenc, J., \& Paraszczakb, J. (2005). Assessing Land Cover Change Resulting from Large Surface Mining Development. International Journal of Applied Earth Observation and Geoinformation, 7, 29-48. https://doi.org/10.1016/j.jag.2004.11.003

Li, L. G., Huang, H. Z., Tan, P. Y., Kwan, H. K. A., \& Chen, Y. H. (2019). Recycling of Marble Dust as Paste Replacement for Improving Strength, Microstructure and Ecofriendliness of Mortar. Journal of Cleaner Production, 210, 55-65. https://doi.org/10.1016/j.jclepro.2018.10.332

Molla, M. B. (2014). Land Use Land Cover Dynamics in the Central Rift Valley Region of Ethiopia. A Case of Arsi Negele District. Academia Journal of Environmental Sciences, 2, 74-88.

Mondal, S., Bandayopadhyay, J., \& Chakravatry, D. (2014). Scientific Investigation of the Environmental Impact of Mines Using Geospatial Techniques over a Small Part of Keonjhar District of Orissa. International Journal of Scientific and Research Publications, 4, 1-8.

Nagendra, H., Darla, M. K., \& Southworth, J. (2004). From Pattern to Process: Landscape Fragmentation and the Analysis of Land Use/Land Cover Change. Agriculture, Ecosystems \& Environment, 101, 111-115. https://doi.org/10.1016/j.agee.2003.09.003

Nartey, K. V., Nanor, N. J., \& Klake, K. R. (2012). Effects of Quarry Activities on Some Selected Communities in the Lower Manya Krobo District of the Eastern Region of 
Ghana. Atmospheric and Climate Sciences, 2, 362-372.

https://doi.org/10.4236/acs.2012.23032

Oke, S. O., \& Ibanesebhur, G. (2010). Impact of Limestone Quarrying on Vegetation and Landform of Ewekoro Cement, Ewekoro Local Government Area, Ogun State, Nigeria. Journal of Botany, 23, 301-368.

Paul, W. B., \& Lisa, S. A. (2011). Agricultural Landscape Change (1937-2002) in Three Townships in Iowa, USA. Landscape and Urban Planning, 100, 202-212. https://doi.org/10.1016/j.landurbplan.2010.12.007

Rana, A., Kalla, P., Verma, K. H., \& Mohnot, K. J. (2016). Recycling of Dimensional Stone Waste in Concrete: A Review. Journal of Cleaner Production, 135, 312-331. https://doi.org/10.1016/j.jclepro.2016.06.126

Schmidt, H., \& Glaesser, C. (1998). Multitemporal Analysis of Satellite Data Their Use in Monitoring of the Environmental Impact of Open Cast Mining Areas in Eastern Germany. International Journal of Remote Sensing, 19, 2245-2260. https://doi.org/10.1080/014311698214695

Sen, A. K. (1972). Agroclimatic Regions of Rajasthan. Annals of Arid Zone, 2, 31-40.

Sen, K. A., \& Gupta, K. N. (1978). Land Use and Land Use Changes in Rajasthan. Proceedings of the Indian National Science Academy, 44-B, 168-175.

Shrestha, R. K., \& Lal, R. (2011). Changes in Physical and Chemical Properties of Soil After Surface Mining and Reclamation. Geoderma, 161, 168-176. https://doi.org/10.1016/j.geoderma.2010.12.015

Singh, A., Jha, K. A., \& Singh, S. J. (2000). Effect of Nutrient Enrichment on Native Tropical Trees Planted on Singrauli Coalfields India. The Journal of the society for Restoration Ecology, 8, 80-86. https://doi.org/10.1046/j.1526-100x.2000.80011.x

Singhal, A \& Goel, S. (2020). Environmental Impacts of Sandstone Quarrying and Its Waste: A Case Study of Jodhpur, India. https://www.researchgate.net/publication/344876280_Environmental_Impacts_of_San dstone_Quarrying_and_Its_Waste_A_Case_Study_of_Jodhpur_India

Souza, A. J., Pinheiro, A. C. B., \& Holanda, F. N. J. (2010). Recycling of Gneiss Rock Waste in the Manufacture of Vitrified Floor Tiles. Journal of Environmental Management, 91, 685-689. https://doi.org/10.1016/j.jenvman.2009.09.032

Sun, L., Wei, J., Duan, D. H., Guo, Y. M., Yang, D. X., Jia, C. et al. (2016). Impact of Land Use and Land Cover Change on Urban Air Quality in Representative Cities of China. Journal of Atmospheric and Solar-Terrestrial Physics, 142, 43-54. https://doi.org/10.1016/j.jastp.2016.02.022

Suraj, R. (2014). Clay Mining and Land Use/Land Cover change of Thrissur district, Kerala, India Using Geospatial Techniques. In ISRS Proceeding Papers of Sort Interactive Session ISPRS TC VIII International Symposium on Operational Remote Sensing Applications . International Society for Photogrammetry and Remote Sensing.

Tabari, H., \& Talaee, P.H. (2011). Analysis of Trends in Temperature Data in Arid and Semi-Arid Regions of Iran. Global and Planetary Change, 79, 1-10. https://doi.org/10.1016/j.gloplacha.2011.07.008

Tesfaye, Y., Roos, A., Campbell, B. M., \& Bohlin, F. (2011). Livelihood Strategies and the Role of Forest Income in Participatory-Managed Forests of Dodola Area in the Bale Highlands, Southern Ethiopia. Forest Policy and Economics, 13, 258-265. https://doi.org/10.1016/j.forpol.2011.01.002

Theobald, D. M. (2001). Land Use Dynamics beyond the American Urban Fringe. Geographical Review, 91, 544-564. https://doi.org/10.1111/j.1931-0846.2001.tb00240.x 
Turkes, M., \& Sumer, U. M. (2004). Spatial and Temporal Patterns of Trends and Variability in Diurnal Temperature Ranges of Turkey. Theoretical and Applied Climatology, 77, 195-227. https://doi.org/10.1007/s00704-003-0024-5

Uy, P. D., \& Nakagoshi, N. (2007). Analyzing Urban Green Space Pattern and Eco-Network in Hanoi, Vietnam. Landscape and Ecological Engineering, 3, 143-157. https://doi.org/10.1007/s11355-007-0030-3

Verburg, H. P., Veldkamp, A., \& Fresco, L. O. (1999). Simulation of Changes in the Spatial Pattern of Land Use in China. Applied Geography, 19, 211-233. https://doi.org/10.1016/S0143-6228(99)00003-X

Vorovencii, I. (2011). Satellite Remote Sensing in Environmental Impact Assessment: An Overview. Bulletin of the Transilvania University of Brasov, 4, 73-80.

Woldeamlak, B. (2002). Land Cover Dynamics since 1950s in Chemoga Watershed, Blue Nile Basin, Ethiopia. Mountain Research and Develop, 22, 263-269. https://doi.org/10.1659/0276-4741(2002)022[0263:LCDSTI]2.0.CO;2

Wright, P., \& Stow, R. (1999). Detecting Mining Subsidence from Space. International Journal of Remote Sensing, 20, 1183-1188. https://doi.org/10.1080/014311699212939

Yavuz Çelik, M., \& Sabah, E. (2008). Geological and Technical Characterisation of Iscehisar (Afyon-Turkey) Marble Deposits and the Impact of Marble Waste on Environmental Pollution. Journal of Environmental Management, 87, 106-116.

https://doi.org/10.1016/j.jenvman.2007.01.004

Zubair, A. O. (2006). Change Detection in Land Use and land Cover Using Remote Sensing Data and GIS: A Case Study of Ilorin and Its Environs in Kwara State.

https://www.geospatialworld.net/wp-content/uploads/2016/04/OpeyemiZubair_Thesis PDF.pdf 